\title{
Konstitusionalisasi Hukum Privat: Beberapa Pandangan yang Berkembang dalam Pengkajian IImu Hukum*
}

\author{
Rahayu Prasetianingsih 22
}

\begin{abstract}
Abstrak
Dalam kajian ilmu hukum, bidang hukum dibagi menjadi dua kelompok besar, yaitu kelompok hukum publik dan privat. secara teoretis kedua kelompok hukum ini dapat dibedakan secara jelas, tetapi pada praktiknya kedua kelompok hukum ini seringkali tumpang tindih, sehingga perbedaan di antara keduanya menjadi samar. Konstitusionalisasi hukum privat merupakan konsep di mana konstitusi mengatur ketentuan-ketentuan yang sebelumnya masuk dalam ranah hukum privat. Konsep ini berkembang seiring dengan berkembangnya pemikiran tentang hak asasi manusia dan konsep fundamental rights. Konsekuensinya, terjadi pencampuran antara hukum privat dengan hukum publik yang aktualisasinya semakin nyata terutama pasca lahirnya peradilan konstitusional yang bertugas untuk menjaga hak-hak fundamental yang dijamin dalam konstitusi.
\end{abstract}

Kata Kunci: konstitusionalisasi, hukum privat, hukum publik, hak-hak fundamental, hak asasi manusia.

\section{Constitutionalization of Privat Law: Some Emerging Thoughts in Legal Studies}

\begin{abstract}
There are distinction between private and public law in the study of law. Theoretically the differentiation is strict and clear, but in practice they often interrelate or even overlap, which leads to vagueness in their distinction. Constitutionalization of private law is when the provision of the constitution interfere the clause in private law. The thoughts of constitutionalization of private law develop as concurrently with human rights and fundamental rights thoughts and concept. Constitutionalization of private law creates the incorporation of private and public laws. Constitutionalization of private law shows by the presence of constitutional court in order to protect constitutional rights.
\end{abstract}

Keywords: constitutionalization, private law, public law, fundamental rights, human rights.

* Artikel ini merupakan bagian dari kegiatan Penelitian Program DIPA Fakultas Hukum Tahun 2013 dengan anggaran yang berasal dari BLU Universitas Padjadjaran Tahun 2013 Berdasarkan Surat Keputusan Rektor Universitas Padjadjaran Nomor: 2097/UN6.A/KP/2013 Tanggal 29 Juli 2013. Penulis tergabung dalam satu tim penelitian yang terdiri dari penulis sebagai Ketua peneliti, dibantu Inna Junaenah, S.H., M.H. sebagai anggota peneliti dan Wulan Kartikasari salah satu Mahasiswa Fakultas Hukum yang membantu menjadi asisten peneliti.

22 Dosen Fakultas Hukum Universitas Padjadjaran, Jl. Dipati Ukur No. 35 Bandung, rahayu_pras@yahoo.com, S.H. (Universitas Padjadjaran) dan M.H. (Universitas Indonesia). 
Rahayu Prasetianingsih: Konstitusionalisasi Hukum Privat: Beberapa Pandangan yang Berkembang dalam Pengkajian Ilmu Hukum

\section{A. Pendahuluan}

Tulisan ini merupakan suatu pengantar untuk mengkaji lebih dalam mengenai pembagian ilmu hukum serta perkembangan dari berbagai macam pembagian ilmu hukum itu sendiri. Konstitusionalisasi hukum privat menjadi satu wacana yang menarik untuk dikaji lebih lanjut dalam khazanah keilmuan hukum, baik dari perspektif hukum publik terutama hukum ketatanegaraan, maupun dari perspektif hukum privat, seiring dengan mengemukanya kajian dan pelaksanaan Hak Asasi Manusia (HAM). Fokus tulisan ini akan lebih menonjolkan sisi hukum ketatanegaraan terutama konstitusi, mengingat latar belakang penulis yang lebih banyak menggeluti bidang ilmu hukum ketatanegaraan. Berbagai tulisan mengenai konstitutionalisasi hukum privat telah berkembang dan dikaji oleh ahli hukum di berbagai negara, terutama di negara-negara Eropa. ${ }^{1}$

Pada negara-negara modern saat ini, tidak ada satu negara pun yang tidak mempunyai konstitusi, walaupun beberapa pakar mempertanyakan apakah Inggris mempunyai konstitusi atau tidak karena tidak ada satu dokumen khusus yang dikatakan sebagai konstitusi. ${ }^{2}$ Namun, Eric Barent mengatakan bahwa secara implisit sebenarnya Inggris mempunyai konstitusi. ${ }^{3}$ Konstitusi adalah serangkaian asas-asas mengenai kekuasaan pemerintah, hak-hak yang diperintah, dan hubungan antara pemerintah dan yang diperintah. ${ }^{4}$ Keberadaan konstitusi, terutama konstitusi tertulis (UUD), bagi suatu negara pada saat ini menjadi hal yang penting untuk dapat membatasi kekuasaan negara agar tidak bertindak sewenang-wenang, dan untuk melindungi hak-hak warga negara serta hak asasi.

1 Salah satunya pernah dibahas dalam Conference on Constitutionalisation of Private Law di Leiden pada 3 Juni 2005, yang merupakan salah satu bagian program penelitian dalam hukum privat dan difasilitasi oleh The E.M. Meijers Institute of Legal Studies Faculty of Law Leiden University. Kegiatan ini, menghasilkan buku kumpulan tulisan berjudul Constitutionalisation of Private Law yang diedit oleh Tom Barkhuysen dan Siewert Lindenbergh. Lihat: Tom Barkhuysen and Siewert D. Lindenbergh (eds), Constitutionalisation of Private Law, Leiden: Martinus Nijhoff Publishers, 2006, (introduction) hlm. viii.

2 Eric Barendt, (An Introduction to Constitutional Law), Oxford: Oxford University Press, 1998, hlm. 26. Dalam tulisannya , Eric Barendt mengatakan: "There is no document in the United Kingdom equivalent, say, to the US Cosntitution of 1787 or to the Constitution of The Fifth Republic in France approved in September 1958, nor for the matter is there a set of statutes clearly indicated by their titles as 'Constitutional' or 'Basic Law'." Lalu, mengutip pendapat Thomas Paine dan Alexis de Tocqueville, Barent menyebutkan: "both Paine and de Tocqueville apparently believed that it is appropriate to use the term 'constitution' only to refer to a higher set of rules, superior or ordinary laws. One characteristic of such higher rules is that a constitution is necessarily rigid. Acceptance of that claim would certainly mean that the United Kingdom does not have one."

3 Barent kemudian menulis: "The view, implicit in the writing of Paine and de Tocqueville, that only set of higher laws can qualify as a constitution is too restrictive. It is surely preferable to conclude that the UK does have that character."

4 Sebagaimana dikutip oleh Sri Soemantri, Pengantar Perbandingan Antar Hukum Tata Negara, Jakarta: Penerbit CV. Rajawali, 1984, hlm. 612-613; lihat juga C.F. Strong, Modern Political Constitution, London: Sidgwick \& Jackson, 1952. 
Dalam kajian ilmu hukum, bidang hukum dibagi menjadi hukum publik dan hukum privat. Hukum tata negara merupakan salah satu bagian atau cabang hukum publik karena membahas tentang negara dan hubungannya dengan warga negara. Konstitusi merupakan aturan hukum yang dibuat oleh rakyat untuk mengatur penyelenggara negara, tetapi dalam perkembangannya konstitusi juga mengatur hubungan antara negara dan rakyatnya, di antaranya berkaitan dengan adanya jaminan HAM dan jaminan hak-hak konstitusional warga negara lainnya. Pemisahan antara hukum publik dan privat ini menjadi samar dalam beberapa bidang kajian ketika dalam perkembangan kekinian, upaya-upaya pemajuan dan penegakan HAM, terutama yang dijamin oleh konstitusi, juga membawa persinggungan antara hukum publik dan hukum privat.

Dalam tulisan ini, akan dikaji lebih lanjut beberapa pandangan tentang konstitusionalisasi hukum privat, apakah konstitusionalisasi hukum privat ini mengancam eksistensi hukum privat, atau justru menjadi bahan pengayaan bagi pengkajian dari ilmu hukum itu sendiri?

\section{B. Pembagian Hukum Publik dan Hukum Privat}

Dalam pengkajian ilmu hukum, dikenal pembagian bidang-bidang hukum ke dalam berbagai kategori, di antaranya pembagian berdasarkan asas, jenis, sumber berlaku, kepentingan yang dilindungi, dan lain sebagainya. Para ahli hukum memiliki pandangan yang berbeda mengenai pembagian antara hukum privat dan hukum publik. Ada yang memandang bahwa pembagian tersebut merupakan pembagian yang mendasar, tetapi ada pula yang berpendapat bahwa pembagian tersebut bukan merupakan hal yang mendasar. ${ }^{5}$

Pembagian antara hukum publik dan privat telah ada dalam tradisi hukum Perancis, dalam pendidikan hukum, juga budaya hukumnya. Di sisi lain, dalam waktu bersamaan kita dapati pada tradisi hukum Inggris yang menganut tradisi Common Law sebagai satu-satunya sumber hukum, mengacu pada pendapat Dicey, dengan kajian konstitusional yang dipengaruhi oleh satu semangat kebebasan yang membedakannya dari konsep hukum di Perancis. ${ }^{6}$ Di lain pihak, baik dalam proses pengadilan, maupun teori-teori akademik hukum Inggris, ide untuk memisahkan hukum publik dengan hukum privat menjadi subjek kajian yang terus berkembang, terlebih dengan diberlakukannya peraturan tentang hak asasi manusia. Saat ini,

5 E. Utrecht dan M. Saleh Djindang, Pengantar Dalam Hukum Indonesia, Cet. Kesebelas, Jakarta: Penerbit \& Balai Buku Ichtiar, 1989, hlm. 33.

6 Mark Freedland and Jean-Bernard Auby (eds), The Public Law/Private Law Divide, Volume 2 in The Series: Studies of The Oxford Institute of European and Comparative Law, London: Hart Publishing, 2006, hlm. 3-4. 
Rahayu Prasetianingsih: Konstitusionalisasi Hukum Privat: Beberapa Pandangan yang Berkembang dalam Pengkajian Ilmu Hukum

pembagian hukum privat dan hukum publik tidak dipertahankan secara ketat, tetapi juga tidak dapat diabaikan begitu saja sehingga pembagian tersebut diletakkan pada posisi yang moderat. ${ }^{7}$

Pembagian hukum publik dan hukum privat dalam praktiknya juga akan berkaitan dengan tradisi hukum yang dianut. Secara historis, tradisi hukum yang ada pada saat ini terbagi ke dalam dua sistem hukum yang berbeda, yaitu Common Law System dan Continental Civil Law System/Roman - Germanic Family. Kedua sistem ini lahir di Eropa, tetapi di antara keduanya berbeda satu sama lain. ${ }^{8}$ Misalnya, dalam tradisi Civil Law (bermula pada tradisi Hukum Romawi) terdapat pemisahan dalam proses peradilan untuk hukum privat dan hukum publik sedangkan dalam tradisi Common Law, baik hukum publik, maupun hukum privat akan diadili oleh peradilan yang sama. ${ }^{9}$ Sebagaimana diungkapkan oleh John Alder bahwa konsep the rule of law yang berkembang di Inggris memberikan perlindungan pada hak-hak individu yang dianggap rendah oleh tradisi Common Law klasik, sedangkan di Perancis pada saat itu tidak dikenal doktrin yang menganggap bahwa kepentingan negara dapat mengesampingkan ordinary law. ${ }^{10}$

Pada tradisi Hukum Romawi, konsep hukum publik bermula pada konsep tentang res publica. Konsep ini merupakan raison d'être (pendorong utama) dari hukum publik. ${ }^{11}$ Konsep res publica ini dibuat oleh Romawi untuk menyelesaikan permasalahan yang dihadapinya terhadap penguasaan kawasan Mediterania. Dalam konsep ini, terdapat public thing (urusan publik) yang dibedakan dari urusan privat dan keberlangsungannya bergantung pada pemisahannya dari urusan privat. ${ }^{12}$ Konsep res publica, sebagaimana dibedakan dari kepentingan privat, merupakan salah satu warisan besar dari tradisi Hukum Romawi yang tercantum dalam pernyataan pembuka Kompilasi Hukum Romawi, inti dari Hukum Justinianus, yang mendefinisikan hukum sebagai :

"The law obtains its name from justice; for (as Celsus elegantly says) law is the art of knowing what is good and just.

7 Ibid, hlm. 4.

8 R. C. Van Caenegern, An Historical Introduction to Private Law, terjemah ke dalam Bahasa Inggris D. E. L. Johnston, Reprinted, Cambridge University Press, 1996, hlm. Vii.

9 Elizabeth Zoller, Introduction to Public Law: a Comparative Study, Leiden: Martinus Nijhoff Publishers, 2008, hlm. 3.

10 John Alder, General Principles of Constitutional Law and Administrative Law, Fourth Edition, Hampshire: Palgrave Macmillan, 2002, hlm. 93.

11 Zoller menyatakan "Without a 'public thing', there would be no need for legal rules to protect and develop the wealth of physical resources (territory, population) and spiritual values (liberty, human rights) that a people inherits from its ancestors and wishes to bequeath to its descendants."

12 Ibid, hlm. 5. 
Rahayu Prasetianingsih: Konstitusionalisasi Hukum Privat: Beberapa Pandangan yang Berkembang dalam Pengkajian Ilmu Hukum

(1) Anyone may properly call us the priest of this art, for we cultivate justice and profess to know what is good and equitable, dividing right from wrong, and distinguishing what is lawful from what is unlawful; desiring to make men good through fear of punishment, but also by the encouragement of reward; aiming (if I am not mistaken) at a true, and not a pretended philosophy.

(2) Of this subject there are two divisions, public and private law. Public law is that which has reference to the administration of the Roman commonwealth; private law is that which concerns the interests of individuals; for there are some things which are useful to the public, and others which are of benefit to private persons. Public law has reference to sacred ceremonies, and to the duties of priests and magistrates. Private law is threefold in its nature, for it is derived either from natural precepts, from those of nations, from those of the Civil Law."

Peter Birks, seorang pakar yang mengkaji Roman Law, membuat suatu taksonomi hukum dengan mempelajari pemikiran dari Gaius yang mengatakan bahwa hukum itu (pada mulanya) tidak memisahkan apakah itu publik atau privat. Pada tradisi Hukum Romawi, hukum privat terbagi antara orang (persons), benda (things), dan tindakan (actions). Setiap kategori terpisah satu sama lain. Benda terdiri dari kepemilikan, kewajiban/tanggung jawab (obligation), dan waris (succession). Obligation terbagi ke dalam contractu dan delictu (pengusung pemikiran Justinianus, pada awal abad ke 6, menambahkan ex contractu dan ex delictu), dan seterusnya dibagi-bagi lagi. ${ }^{13}$

Hukum privat menyangkut hubungan antarindividu yang diharapkan dapat harmonis. Jika terjadi persengketaan dalam hubungan tersebut, maka pengadilan dapat melakukan intervensi untuk menyelesaikan persengketaan tersebut dengan damai dan otoritatif. Hukum privat merupakan satu rezim hukum yang memberikan kebebasan bagi para pihak untuk menentukan sendiri penyelesaian sengketanya berdasarkan konsep dan kepentingannya. ${ }^{14}$ Secara singkat, dikatakan oleh Robert Stevens sebagaimana dikutip Nolan \& Robertson, "Private law is simply about the rights we have one against another". ${ }^{15}$

13 Mitchell McInnes, "Taxonomic Lessons for the Supreme Court of Canada" dalam buku Structure and Justification in Private Law Essay for Peter Birks yang disusun oleh Charles Rickett \& Ross Grantham (eds.), Portland: Hart Publishing, 2008, hlm. 83.

14 Ernest J Weinrib, "The Normative Structure of Unjust Enrichment", dalam buku Structure and Justification in Private Law Essay for Peter Birks yang disusun oleh Charles Rickett \& Ross Grantham (eds), Op. Cit., hlm. 38.

15 Donal Nolan and Andrew Robertson. "Rights and Private Law, http://www.hartpub.co.uk/pdf/samples/9781849461429sample.pdf, hlm. 2. 
Rahayu Prasetianingsih: Konstitusionalisasi Hukum Privat: Beberapa Pandangan yang Berkembang dalam Pengkajian Ilmu Hukum

Lalu, bagaimana dengan pengkajian tentang pembagian lapangan hukum publik dan hukum privat di Indonesia, yang sangat jelas perkembangan pengkajian ilmu hukumnya dipengaruhi oleh hukum Belanda atas asas konkordansi, yang mendapat pengaruh dari hukum Perancis? Pengajaran ilmu hukum pada mahasiswa di Fakultas Hukum diawali dengan pengenalan berbagai pengertian dalam ilmu hukum, selain berdasarkan pendapat para ahli hukum Indonesia, memang banyak mengambil sumber dari pendapat para ahli hukum Belanda, yang beberapa diantaranya penulis kutip dalam tulisan ini.

Achmad Sanusi membagi jenis hukum berdasarkan pembagian menurut sumber berlaku dan bentuknya, kepentingan-kepentingan yang diatur/dilindunginya, hubungan aturan hukum satu sama lain, pertaliannya dengan hubungan-hubungan hukum implementatif, serta pelaksanaan sanksinya tersebut. Pada klasifikasi berdasarkan kepentingan menurut Achmad Sanusi, hukum yang mengatur kepentingan perseorangan dan kepentingan negara yang dalam kedudukannya bukan sebagai penguasa, adalah hukum privat; sedangkan hukum publik adalah hukum yang mengatur/melindungi kepentingan-kepentingan negara sebagai penguasa. ${ }^{16}$

Pendapat Achmad Sanusi tersebut sejalan dengan pendapat van Apeldoorn yang membagi peraturan hukum antara hukum publik dan hukum privat atas dasar kepentingan yang dilindungi oleh peraturan hukum tersebut. Hukum publik mengatur kepentingan umum (publik), sedangkan hukum privat mengatur kepentingan khusus atau privat. Namun, anggapan ini menurut E. Utrecht adalah anggapan yang kurang tepat, karena bisa saja hukum publik maupun hukum privat mengatur suatu kepentingan umum. ${ }^{17}$

Scholten membagi hukum berdasarkan asas-asas dari masing-masing peraturannya. Menurut Scholten, hukum privat merupakan hukum biasa (gemene recht) karena memuat asas-asas umum (biasa), yang negara juga tunduk pada hukum umum ini selama tidak diadakan pengecualian terhadapnya. Pengecualian dimaksud ada dalam hukum publik, yaitu hukum yang istimewa (bijzonder recht) karena berlandaskan pada asas-asas istimewa. Hukum publik akan membatasi hukum privat, walaupun tidak melenyapkannya. ${ }^{18}$

Utrecht mengkritik pendapat $A$. Thon yang membagi hukum menjadi dua golongan yaitu golongan hukum publik dan golongan hukum privat atas dasar cara

16 Achmad Sanusi, Pengantar IImu Hukum dan Pengantar Tata Hukum Indonesia, Edisi Ke IV, Bandung: Penerbit Tarsito, 2002.

17 E. Utrecht dan M. Saleh Djindang, Pengantar dalam Hukum Indonesia, Op. cit., hlm. 32.

18 Ibid, hlm. 33. 
mempertahankan hak-hak yang ditimbulkan oleh hukum tersebut. Secara umum, negaralah yang mempertahankan hak tersebut, tetapi apabila hak yang dipertahankan adalah atas permintaan pihak (individu) yang dirugikan akibat adanya pelanggaran hak, maka peraturan hukumnya termasuk ke dalam golongan hukum privat. Menurut Utrecht, terdapat kondisi yang bertentangan dengan apa yang dikemukakan A. Thon, dengan memberikan contoh di antaranya permohonan pembatalan perkawinan oleh jaksa (pemerintah) untuk melindungi suatu hak privat. Utrecht juga menyatakan bahwa perbedaan cara mempertahankan hak hanya merupakan akibat dari pembagian hukum antara hukum publik dan hukum privat. ${ }^{19}$

Utrecht menyatakan bahwa pada hakikatnya setiap aturan hukum bertujuan mengatur dan memaksa, tetapi terdapat golongan aturan yang baru dapat memaksa apabila para pihak tidak dapat menyelesaikan masalah dengan aturan yang disepakati oleh mereka sendiri. Dalam hal tidak terdapat penyelesaian hukum dengan kesepakatan, maka pemerintah yang bertindak untuk menyelesaikannya. Pada bagian lain, menurut Utrecht, terdapat aturan yang secara a priori memaksa, tidak ada kebebasan bagi individu untuk memilih melainkan tunduk pada aturan tersebut. Pembagian hukum privat dan publik menurutnya kurang lebih sama dengan pembagian aturan yang mengatur dan memaksa tersebut.

Freedland berusaha untuk membungkus isu tentang pemisahan antara hukum publik dan hukum privat sepanjang memungkinkan dan memfokuskan pada saling melengkapinya atau persinggungan antara bagian yang dianggap sebagai hukum publik dan bagian yang dianggap sebagai hukum privat. Freedland mengatakannya sebagai permasalahan yang multidimensi dengan alasan bahwa dalam pemisahan antara hukum publik dan hukum privat terdapat banyak dimensi yang harus dibedakan yang sekurang-kurangnya dapat dikelompokkan ke dalam tiga dimensi, meliputi:

1. dimensi yurisdiksi (the jurisdictional dimension);

2. dimensi prosedural (the procedural dimension); dan

3. dimensi doktrinal atau substantif (the doctrinal or substantive dimension).

Pada dimensi yurisdiksi, dapat diidentifikasi orang/individu, institusi, aktivitas/kegiatan, atau fungsi-fungsi di mana hukum publik maupun hukum privat dapat diterapkan. Pada dimensi prosedur, dapat dibedakan antara pengaturan mengenai proses dan prosedur ajudikasi/peradilannya yang dapat diterapkan, baik dalam hukum publik maupun hukum privat. Pada dimensi substantif atau doktrinal, dapat diidentifikasi bahwa aturan-aturan atau prinsip-prinsip yang secara spesifik masuk dalam bidang hukum publik dan hukum privat, menjadi cukup kompleks 
Rahayu Prasetianingsih: Konstitusionalisasi Hukum Privat: Beberapa Pandangan yang Berkembang dalam Pengkajian Ilmu Hukum

karena hal tersebut tidak dapat dipahami hanya dalam satu dimensi saja, tetapi juga harus diamati dari semua perspektif. ${ }^{20}$

\section{Tentang Hak dan Hak-Hak Fundamental}

Sebagaimana telah disinggung sebelumnya, konsep konstitusionalisasi hukum privat muncul/berkembang karena berkembangnya pemikiran tentang hak-hak asasi manusia dan konsep fundamental rights. Terdapat berbagai pendapat tentang apa yang dimaksud dengan hak (rights), di antaranya Nolan \& Robertson dalam artikelnya dengan judul "Rights and Private Law" membedakan hak dalam hukum privat dengan hak dalam konsep HAM. Hak dalam hukum privat lebih mengutamakan hak antara satu individu melawan yang lainnya, yang tentunya berbeda dengan hak yang berhubungan dengan negara (contohnya HAM). Setidaknya terdapat tiga jenis perbedaan pengertian hak dipandang dari hukum privat, yaitu:

1. Hak gugat (claim right), sebagai sebuah "claim" tentang hak hukum yang berhubungan dengan kewajiban hukum. Contohnya adalah hak untuk tidak diganggu/disiksa, atau hak seseorang, disaat yang sama orang lain untuk tidak boleh melanggar wilayah atau melintas di tanah hak miliknya. Hak ini pada dasarnya sangat khas, absolut dan menentukan, maka dalam penegakannya tidak dapat dikesampingkan. Hak milik yang utama ini dapat dibedakan dari hak milik yang kedua, yang dipicu oleh pelanggaran terhadap hak milik yang utama yang berhubungan dengan kewajiban sekunder untuk ganti kerugian.

2. Hak-hak moral (moral rights), yaitu hak moral yang terlepas dari negara. Hak moral ini dapat digambarkan dalam pengertian di luar hukum, meskipun mungkin hak itu atas dasar hukum berupa hak milik yang harus ditegakkan oleh negara. Nolan \& Robertson, mengutip pendapat Robert Stevens, yang menyatakan bahwa hak moral ini muncul secara alamiah dari pengalaman manusia itu sendiri. Namun, Stevens tidak menjelaskan lebih lanjut apakah hak moral itu merupakan hak hukum atau setidaknya berhubungan dengan kewajiban moral yang menghendaki adanya ganti kerugian. Bagaimanapun, Nolan \& Robertson menyatakan penting untuk membedakan pengertian hak dalam hukum privat antara hak hukum dan hak moral. Menganggap hak-hak yang berasal dari hukum privat sama sekali bukan merupakan implikasi dari normanorma tertentu, adalah salah.

3. Hak-hak yang lebih umum (general rights), seperti hak atas integritas pribadi (rights of bodily integrity) atau hak atas reputasi (right to reputation). Hak ini 
Rahayu Prasetianingsih: Konstitusionalisasi Hukum Privat: Beberapa Pandangan yang Berkembang dalam Pengkajian Ilmu Hukum

digambarkan oleh James Penner sebagai alat untuk menggambarkan konstelasi norma-norma yang mengatur mereka atas dasar kepentingan yang tercermin dalam berbagai sistem norma itu. ${ }^{21}$

Lebih lanjut, Nolan dan Robertson menyatakan terdapat berbagai pandangan ahli dalam membahas mengenai hak-hak dan negara serta hubungannya dengan hukum privat, di antaranya pendapat yang menyatakan bahwa hak-hak dalam hukum privat hadir bebas dari pengaruh negara. Namun, terdapat juga pendapat yang menyatakan bahwa hak-hak dalam hukum privat hanya ada ketika negara berkehendak untuk mengenali dan menegakkannya. Inilah yang kemudian memunculkan pertanyaan apakah seseorang mempunyai hak yang berhadapan negara di mana negara mengakui bahwa hak-hak privat orang tersebut berhadapan dengan hak-hak individu lainnya. Dalam hal ini terdapat tiga tingkatan jawaban: Pertama, tingkat di mana terdapat hak gugat atau hak domestik biasa. Dalam lingkup hukum positif, seseorang dapat dikatakan mempunyai hak yang bertentangan dengan negara, ketika negara memberikan efek melawan hak-hak individu lainnya untuk memulihkan hak-haknya tersebut; Kedua, pada tingkat hak-hak konstitusional; dan Ketiga, pada tingkat hak-hak moral. ${ }^{22}$

Dalam hal terjadinya pergeseran dari aturan yang semula merupakan ranah hukum privat menjadi masuk ke dalam hukum publik, maka timbul anggapan bahwa negara sudah masuk ke dalam ranah-ranah privat yang seharusnya dihindari oleh negara. Pembagian atau pemisahan hukum publik dengan hukum privat bukanlah hal yang sederhana. Menurut Allen M. Linden beberapa upaya dilakukan di antaranya: Pertama, menemukan bahwa pemisahan tersebut merupakan hal yang esensial dan multidimensional, di mana keduanya harus dipelihara dengan berbagai tingkatan fleksibilitas dalam setiap dimensinya; Kedua, mengetahui bahwa hukum publik merupakan bagian penting dalam persilangan dengan hukum privat dan harus diakui dengan ruang untuk mengatur melalui hukum. Kita temukan bahwa HAM merupakan yang diperdebatkan dalam hubungan antara hukum publik dengan hukum privat. Tipe lain yang ditempatkan antara hukum publik dan privat adalah ketentuanketentuan tentang persaingan usaha (competition law) atau hukum hak atas kekayaan intelektual (intellectual property law). Perdebatan lain tentang hubungan antara hukum publik dan hukum privat adalah tentang di mana meletakkan hukum pidana, hukum keluarga, dan hukum ketenagakerjaan dalam sistem klasifikasi ini,

21 Donal Nolan and Andrew Robertson, "Rights and Private Law" http://www.hartpub.co.uk/pdf/samples/9781849461429sample.pdf, hlm. 9.

22 Ibid, hlm. 11. 
Rahayu Prasetianingsih: Konstitusionalisasi Hukum Privat: Beberapa Pandangan yang Berkembang dalam Pengkajian Ilmu Hukum

sehingga dapat dipahami dan dipertahankan adanya pemisahan antara hukum publik dan hukum privat. ${ }^{23}$

Tom Barkhuysen menyatakan bahwa pandangan tradisional tentang hak-hak fundamental menjadikan hal tersebut berfungsi sebagai penjaga/pelindung dari campur tangan publik terhadap hubungan privat. Namun, dalam membahas pengaruh HAM terhadap hukum privat, Barkhuysen mengemukakan beberapa model, yaitu:

1. Direct effect of human rights on private - horizontal - relations, also called direct effect on third parties; Pada model ini, diartikan bahwa standar hak asasi manusia diterapkan secara langsung dan mengikat para pihak dalam hubungan hukum privat;

2. Indirect effect of human rights on private relations through the interpretation of applicable general open legal standards such as good faith, reasonableness and fairness and due care, for instance in the context of tort. Model ini cenderung menerima prinsip-prinsip HAM hanya sebagai hubungan antara negara dengan warga negaranya, walaupun demikian mungkin saja prinsip HAM itu merupakan cerminan dari nilai sosial dalam masyarakat yang menjadikannya bagian dari hubungan hukum privat dan dengan sendirinya muncul dalam praktik;

3. Indirect effect through legislation that implements human rights that apply in private relations. These may be standards of a various nature that result in a specific application of human rights in private relations, such as the protection of ownership, privacy and the principle of equality;

4. Indirect effect of human rights by reading these in, as it were, a generally applicable (personal) right, which affects overall law including private legal relations;

5. A certain effect of human rights through the involvement of the (state) court in disputes between private parties;

6. No effect at all of human rights on private relations. ${ }^{24}$

Robert Alexy, dalam artikelnya yang berjudul "Discourse Theory and Fundamental Rights", mengemukakan tiga konsep tentang hak-hak fundamental, yaitu konsep formal, konsep substantif, dan konsep prosedural. Konsep formal dari hak-hak fundamental didefinisikan sebagai hak-hak yang tercantum dalam konstitusi, atau beberapa yang menjadi bagiannya, atau hak-hak yang dinyatakan oleh konstitusi sebagai hak fundamental, atau jika hak-hak tersebut menurut konstitusi

23 Allen M. Linden, "Public Law and Private Law: Their Frontier from the Perspective of a Tort Lawyer", Les Cahier de Droit, Vol. 17, Issue 4, 1976, hlm. 837, http://id.erudit.org/iderudit/042139ar.

24 Tom Barkhuysen and Siewert D. Lindenbergh (eds), Constitutionalisation of Private Law, Op. cit., hlm. 19. 
Rahayu Prasetianingsih: Konstitusionalisasi Hukum Privat: Beberapa Pandangan yang Berkembang dalam Pengkajian IImu Hukum

diklasifikasikan sebagai hak-hak yang memerlukan perlindungan khusus, contohnya mekanisme constitutional complaint melalui Peradilan Konstitusi. ${ }^{25}$ Pengaruh dari hak fundamental terhadap hukum privat merupakan suatu fenomena yang relatif baru dalam sejarah hukum, suatu perkembangan yang didorong terus-menerus oleh perkembangan hak-hak fundamental dan basic rights di abad-abad terakhir. Fundamental rights, dalam beberapa kondisi, masih merupakan bola liar (odd balls) dalam hukum privat. Beberapa ahli berpendapat bahwa fundamental rights, secara khusus, merupakan hubungan antara negara dan warga negaranya. Para ahli lain menyatakan bahwa pada kenyataannya fundamental rights berakar pada hukum privat. Stathis Banakas ${ }^{26}$ menyatakan bahwa pada bentuk asalnya dalam Hukum Romawi, hukum privat telah mencakup perlindungan terhadap beberapa aspek dari martabat manusia, bahkan jauh sebelum lahirnya pemikiran tentang konstitusi. ${ }^{27}$ Lebih lanjut, Banakas memberikan contoh prinsip iniuria and lesio enormis in the jus civile yang memberikan perlindungan minimum bagi warga non-Romawi dari kesewenang-wenangan Penguasa Romawi. Prinsip tersebut menjadi prinsip yang mengawali International Humanitarian Law. Tentu saja, terhadap hak-hak warga negara yang dalam pandangan modern dikatakan serupa dengan hak fundamental yang pada masa Romawi merupakan perlindungan dari hukum privat dan hanya dapat digugat dengan prosedur hukum keperdataan. Meskipun secara historis hak fundamental mungkin menjadi bagian dari hukum privat, sekumpulan hak tersebut sekarang dipisahkan, dikelompokkan dalam kelompok hukum tertentu dengan fungsi yang berbeda, yang pada saat ini diposisikan atau dikatakan sebagai hak fundamental dalam hukum privat. ${ }^{28}$

\section{Konstitusionalisasi Hukum Privat}

Istilah konstitusionalisasi (constitutionalization) secara umum bukan hanya

25 Robert Alexy, "Discourse Theory and Fundamental Rights", dalam buku Arguing Fundamental Rights, yang disusun oleh A.J. Menendez \& E. O. Eriksen (eds), Dordrecht: Springer, 2006, hlm. 15.

26 Lihat Stathis Banakas, "The Constutionalisation of Private Law in The UK: Is There An Emperor Inside The New Clothes?" dalam buku Constitutionalisation of Private Law yang disusun oleh Tom Barkhuysen and Siewert D. Lindenbergh (eds.), Op. Cit, hlm. 83.

27 Secara tegas Banakas mengatakan: "It is important to note that Private law, for both historical (pre-existed long before any notion of Constitutional order or Constitution) and social (being the law that determines the basic status and personal rights of individual private human beings) reasons, has been the one first to influence the other, Constitutional law, in the area of protection of human dignity. The rights to life, freedom, bodily integrity, property and reputation were, of course, protected in the jus civile long before they appeared in any list of basic Constitutional rights."

28 Wim Voermans, "Applicability of Fundamental Rights in Private Law: What is the Legislature to do? An Intermezzo from a Constitutional Point of View", dalam buku Constitutionalisation of Private Law yang disusun oleh Tom Barkhuysen and Siewert D. Lindenbergh (eds), Op. Cit, hlm. 33. 
dilekatkan pada upaya membandingkan antarrezim hukum yang berbeda, dalam hal ini rezim hukum publik dan rezim hukum privat. Istilah konstitusionalisasi di Eropa semakin mengemuka sejalan dengan terbentuknya Uni Eropa yang mengarah pada konstitusionalisasi regional Eropa. Konstitusionalisasi diartikan sebagai sekumpulan argumen, prinsip, serta kelengkapan prosedur dalam suatu masyarakat demokratis dalam suatu periode sejarah tertentu yang menentukan hakikat dari the supreme law of the land untuk mendorong strategi pembatasan kekuasaan publik dan perlindungan hak-hak individu. Konsitusionalisasi merupakan suatu proses pembentukan ketentuan-ketentuan konstitusi. ${ }^{29}$ Pengertian ini sejalan dengan makna dari konstitusionalisme menurut Bagir Manan yang pada hakikatnya merupakan pembatasan terhadap kekuasaan-kekuasaan yang ada dalam negara pada satu sisi dan jaminan hak-hak warga negara pada sisi yang lain. ${ }^{30}$

Versi yang lebih modern dari pembedaan yang esensial antara hukum publik dan hukum privat adalah pendapat yang dikemukakan oleh pendapat Ernest J. Weinrib dalam artikel Nolan \& Robertson. Menurut Weinrib, menjadi penting untuk membedakan dengan tajam antara hukum dengan politik serta antara keadilan korektif dan distributif. Keadilan distributif berada pada wilayah politik; di mana konstitusi harus ditaati oleh negara. Keadilan korektif di sisi lain tidak berhubungan dengan tujuan korektif; tidak ada tujuan lain dari hukum privat, hanya hukum privat itu saja. ${ }^{31}$ Fungsi dari hak-hak fundamental lebih dekat hubungannya dengan pemisahan antara hukum publik dan hukum privat sebagaimana telah berkembang lebih dari dua abad lamanya. Montesquieu merupakan salah seorang tokoh yang mengemukakan pemisahan secara tajam kedua bidang hukum tersebut. Dia memisahkan hukum publik dengan hukum privat yang didasarkan pada ketentuan lois civiles, dan lingkungan publik di bawah ketentuan lois politiques, dimana subjek dari hukum privat adalah orang/pribadi hubungannya dengan kepentingan selain negara. Kebebasan orang/pribadi hanya dapat terwujud dengan memisahkan kedua lingkungan hukum tersebut (hukum publik dan hukum privat). Sebagai konsekuensinya adalah orang/pribadi tidak perlu mengikuti kepentingan publik. Mereka adalah otonom dan dapat menentukan pilihannya sendiri tentang apa yang menurutnya adil. Hukum privatlah yang memungkinkan mewujudkan hal tersebut. Dalam lingkup publik, orang/pribadi ini dapat dipaksakan untuk tunduk pada

Sergio Fabbrini, "Constitutionalization as an Open Process: Constituting Compound Polities From Philadelphia to Brussels", <http://web.unitn.it/files/download/9722/wpfabbrini.pdf>diunduh 16 Juli 2014.

30 Bagir Manan, Pertumbuhan dan Perkembangan Konstitusi Suatu Negara, Bandung: Penerbit CV. Mandar Maju, 1995, hlm. 6.

31 Sergio Fabbrini, “Constitutionalization as an Open Process...”, Op. Cit, hlm. 20. 
Rahayu Prasetianingsih: Konstitusionalisasi Hukum Privat: Beberapa Pandangan yang Berkembang dalam Pengkajian IImu Hukum

keputusan yang tidak mereka sukai, tetapi hal ini disahkan oleh keputusan yang diakui sebagai demokratis. ${ }^{32}$

Invasi hukum publik ke dalam hukum privat bukanlah merupakan suatu hal yang baru, sebagai contoh bahwa lahirnya skema kompensasi bagi pekerja yang ditentukan oleh pemerintah di awal abad ini merupakan reaksi dari gagalnya sistem keperdataan untuk dapat memberikan penyelesaian yang memuaskan bagi kerugian para pekerja. ${ }^{33}$ Contoh lain dari skema hukum publik adalah adanya wacana pemberian kompensasi bagi korban tindak kejahatan dengan sumber dari kekayaan atau keuangan negara, bukan berdasarkan adanya tuntutan ganti kerugian dari korban kepada pelaku. ${ }^{34}$

Meskipun terdapat berbagai pandangan dan perkembangan yang digambarkan tentang konstitusionalisasi hukum privat, tetapi secara umum dapat ditarik dua pandangan tentang perdebatan konstitusionalisasi hukum privat ini. Pertama, hakhak dasar/fundamental rights tidak dapat secara sederhana dikatakan sebagai konsep hukum publik yang menginvasi atau memasuki ranah hukum privat, meskipun masing-masing (hukum publik dan hukum privat) mempunyai akar atau asal usul konsepnya sendiri yang mengawali konsep hukum yang membedakannya dan menjelaskan nilai mana yang menguatkan ketentuan hukumnya secara keseluruhan; kedua, hak-hak dasar/ fundamental rights, terlepas dari akarnya apakah berasal dari hukum publik maupun hukum privat, dapat membantu menjadi sumber inspirasi bagi hukum privat dan sebagai tanda peringatan bahwa martabat manusia mungkin sedang terancam. Kedua pandangan tersebut mendukung kesimpulan bahwa hakhak fundamental secara substansial memberikan nilai tambah terhadap hukum privat, atau dengan kata lain hukum privat memberikan nilai tambah dalam mewujudkan hak-hak dasar. ${ }^{35}$

Konsep konstitusionalisasi hukum privat menurut Anna Lytvynyuk merupakan hasil dari pemikiran Hukum Jerman pada tataran hak-hak konstitusional yang memungkinkan untuk muncul dalam sengketa individual satu sama lain. Perdebatan berkisar pada gagasan bahwa jika individu dapat menggugat hak konstitusionalnya bukan hanya terhadap negara melainkan di antara mereka karena ketentuan mengenai hak konstitusional merupakan ketentuan yang lebih tinggi yang dapat secara langsung diterapkan dalam hubungan privat dan tidak diperlukan adanya ketentuan hukum perdata (civil and commercial codes, special civil laws, etc.).

32 Ibid.

33 Allen M. Linden, Loc. cit.

34 Ibid.

35 Tom Barkhuysen and Siewert Lindenbergh (eds), Constitutionalisation of Private Law, Op. Cit, hlm. Viii. 
Rahayu Prasetianingsih: Konstitusionalisasi Hukum Privat: Beberapa Pandangan yang Berkembang dalam Pengkajian Ilmu Hukum

Kesimpulan dari ide tersebut adalah sengketa privat memungkinkan sekali untuk langsung dibawa kepada peradilan konstitusi (Mahkamah Konstitusi) dengan mengabaikan pemikiran mengenai struktur peradilan umum (civil court), peradilan administrasi, peradilan perburuhan, dan lain-lain. ${ }^{36}$ Dengan demikian, tentunya dalam negara harus ada peradilan konstitusi (Mahkamah Konstitusi tersendiri) yang terpisah dari peradilan umum maupun peradilan lainnya.

Pengaruh hak-hak fundamental dalam hukum privat bergantung setidaknya sebagiannya-kepada kerangka pemikiran konstitusional pada saat pembentukannya oleh pembentuk UUD (legislator). ${ }^{37}$ Pada umumnya, konstitusi yang ada akan memuat jaminan HAM sehingga para pakar menyatakan bahwa salah satu materi muatan konstitusi adalah adanya jaminan HAM. ${ }^{38}$ Namun, apakah konstitusi akan secara detail memuat jaminan tersebut atau tidak tentunya sangat bergantung kepada pertimbangan dari pembentuknya dan dalam pelaksanaannya, hal tersebut akan sangat bergantung pada penafsiran dari hakim terhadap konstitusi itu sendiri.

Konstitusionalisasi hukum privat juga dapat digambarkan sebagai suatu peningkatan pengaruh hak-hak dasar dalam hubungan antara individu dan individu lainnya yang berkembang dari hubungan antara pemerintah/negara dan warga negaranya. Hak-hak ini dapat diatur dalam konstitusi negara, piagam HAM atau hukum tidak tertulis sekalipun. ${ }^{39}$ Hak dasar ini memengaruhi hubungan hukum privat dengan dua cara. Pertama, secara tidak langsung, dimana hak tersebut hanya muncul melalui aturan-aturan hukum privat, seperti halnya konsep good faith, good morals. Kedua, secara langsung, misalnya dalam hukum kontrak berlaku prinsip kebebasan berkontrak (freedom to contract) yang merupakan salah satu hak dasar, walaupun mungkin sekali untuk tidak dicantumkan dalam konstititusi negara. Meskipun kemudian dapat ditemukan bahwa hak dasar semacam kebebasan berkontrak dibatasi oleh hak dasar lainnya, seperti freedom of speech, freedom of religion atau yang lainnya. ${ }^{40}$

Konstitusionalisasi hukum privat adalah pertemuan antara hak-hak fundamental dan hukum privat atau antara peraturan perundang-undangan dan hukum privat,

36 Anna Lytvynyuk, "Constitutionalisation of Private Law", dalam buku New Direction of Comparative Law, yang disusun oleh Antonina Bakardjieva Engelbrekt (eds), Cheltenham: Edward Elgar Publishing Limited, hlm. 202.

37 Tom Barkhuysen and Siewert Lindenbergh (eds), Constitutionalisation of Private Law, Op. Cit., hlm. Vii.

38 Sri Soemantri, Pengantar Perbandingan Antar Hukum Tata Negara, Op. Cit., hlm. 63.

39 Jan Smits, "Private Law and Fundamental Rights: A Sceptical View", dalam buku Constitutionalisation of Private Law, yang disusun oleh Tom Barkhuysen and Siewert Lindenbergh (eds), Leiden: Martinus Nijhoff Publishers, 2006, hlm. 10.

40 Ibid, hlm. 12-13. 
Rahayu Prasetianingsih: Konstitusionalisasi Hukum Privat: Beberapa Pandangan yang Berkembang dalam Pengkajian Ilmu Hukum

juga relevansi antara budaya dan hukum privat. ${ }^{41}$ Jika kita kembali pada kontrak pada hukum privat akan ditemukan diskursus yang menarik tentang konstitusionalisasi hukum privat. Dampak dari latar belakang hukum ketatanegaraan terutama konstitusi terhadap perkembangan hukum privat juga menjadi perhatian yang menarik. Tidak hanya di Jerman, kasus konstitusionalisasi hukum privat juga terjadi di Amerika Serikat dalam kasus (New York Times v. Sullivan). Berdasarkan Common Law kasus penghinaan didasarkan pada ketentuan konstitusi yaitu perlindungan kebebasan berbicara. Kasus serupa, kasus Roe v. Wade menyatakan bahwa perempuan mempunyai hak konstitusional untuk memilih menggugurkan kandungannya berdampak pada bidang hukum yaitu "perbuatan melawan hukum". ${ }^{2}$ Menurut Jan Smits, meningkatnya pengaruh hak fundamental dalam hubungannya dengan hukum privat, hak fundamental menjadi hak yang pada mulanya berkembang mengatur hubungan negara dengan warga negaranya. ${ }^{43}$

Di Indonesia sendiri perkembangan interaksi antara hukum publik dan hukum privat berlangsung sejalan dengan berkembangnya pengkajian ilmu hukum, praktik pelaksanaan peraturan perundang-undangan maupun tindakan-tindakan hukum yang dilakukan oleh masyarakat serta perkembangan ketatanegaraan terutama pasca reformasi konstitusi 1999 sampai dengan 2002. Sebagai contoh adalah perkembangan dalam hukum ketenagakerjaan, dimana dalam hak atas pekerjaan menurut UUD 1945 terdapat di dalamnya juga hak atas penghidupan yang layak bagi kemanusiaan. ${ }^{44}$ Keterlibatan pemerintah dalam menentukan upah minimum yang layak diterima oleh pekerja merupakan salah satu bentuk konstitusionalisasi dari hubungan privat antara pekerja dan pengusaha yang pada mulanya murni hubungan hukum privat berdasarkan perjanjian kerja. Walaupun untuk bidang hukum ketenagakerjaan ini juga terdapat pandangan yang skeptis seperti yang dikemukakan oleh Guy Mundlak yang mengatakan: ${ }^{45}$

41 Christian Twigg-Flesner (ed.), The Cambridge Companion to European Union Private Law, Cambridge: Cambridge University Press, 2010, hlm. 760-762.

42 Basil Markesinis, "German Law of Obligations", Volume 2 the Law of Torts: A Comparative Introduction, 1998, hlm. 4.

43 Wim Voermans, "Applicability of Fundamental Rights in Private Law: What is The Legislature To Do? An Intermezzo From A Constitutional Point of View", dalam buku Constitutionalisation of Private Law, yang disusun oleh Tom Barkhuysen and Siewert Lindenbergh (eds), Op. Cit., hlm. 33.

44 Pasal 27 ayat (2) UUD 1945: "Tiap-tiap warga negara berhak atas pekerjaan dan penghidupan yang layak bagi kemanusiaan".

45 Guy Mundlak, "Human Rights and the Employment Relationship: A Look Through the Prism of Juridification", dalam buku Human Rights in Private Law yang disusun oleh Daniel Friedmann and Daphne Barak-Erez(eds), Portland: Hart Publishing, 2001, hlm. 328. 
Rahayu Prasetianingsih: Konstitusionalisasi Hukum Privat: Beberapa Pandangan yang Berkembang dalam Pengkajian Ilmu Hukum

"The developing discourse of human rights in the workplace must therefore be viewed not only as progress, but also as a failure. The regulatory solution risks the marginalisation of further efforts to reconsider a collective-based system that is better adjusted to the new labour market. It is better to consider the new juridification as a limited response that must be complemented by other forms of reflexive regulation, rather than the conclusive source for workplace related norms."

Pasca dibentuknya Mahkamah Konstitusi dengan segala kewenangan yang dimilikinya, ${ }^{46}$ sebagai buah reformasi konstitusi, merupakan bentuk nyata proses konstitusialisasi hukum privat di Indonesia. Putusan Mahkamah konstitusi yang sangat mengemuka di antaranya putusan terhadap permohonan Nomor 46/PUUVIII/2010 tentang Pengujian UU No. 1 Tahun 1974 tentang Perkawinan, yang dikeluarkan Mahkamah Konstitusi pada tanggal 17 Februari 2012. Putusan ini mengemuka bukan hanya disebabkan pemohon yang merupakan salah satu selebriti di Indonesia yang juga melibatkan salah satu mantan pejabat yang juga terkemuka, tetapi isi putusan menimbulkan pro dan kontra di kalangan masyarakat Indonesia yang secara umum masih sangat religius, ${ }^{47}$ termasuk di kalangan akademisi dan praktisi hukum. Isi putusan Mahkamah lebih menarik untuk dikaji dalam tulisantulisan ilmiah maupun diskursus mengenai hukum. Dalam pengkajian dan praktik hukum di Indonesia, persoalan perkawinan dan keluarga diletakkan pada bidang kajian hukum privat, tetapi pada perkara pengujian UU Perkawinan ini, atas alasan adanya pelanggaran terhadap hak konstitusional seorang anak untuk mempunyai hubungan keperdataan dengan ayah kandungnya, maka Mahkamah Konstitusi menyatakan bahwa:

"Pasal 43 Ayat (1) UU Perkawinan 'Anak yang dilahirkan di luar perkawinan hanya mempunyai hubungan perdata dengan ibunya dan keluarga ibunya'. Bertentangan dengan UUD 1945 secara bersyarat (conditionally unconstitutional), yakni bertentangan atau inkonstitusional sepanjang ayat tersebut dimaknai menghilangkan hubungan perdata antara seorang anak dan laki-laki yang dapat dibuktikan berdasarkan ilmu pengetahuan dan

Pasal 24 C ayat (1) UUD 1945 “Mahkamah Konstitusi berwenang mengadili pada tingkat pertama dan terakhir yang putusannya bersifat final untuk menguji undang-undang terhadap Undang-Undang Dasar, memutus sengketa kewenangan lembaga negara yang kewenangannya diberikan oleh Undang-Undang Dasar, memutus pembubaran partai politik, dan memutus perselisihan tentang hasil pemilihan umum".

47 Mengingat Putusan MK berhubungan dengan nilai-nilai religius masyarakat yang menyangkut nilai-nilai dari agama yang dianut. 
Rahayu Prasetianingsih: Konstitusionalisasi Hukum Privat: Beberapa Pandangan yang Berkembang dalam Pengkajian IImu Hukum

teknologi dan/atau alat bukti lain menurut hukum mempunyai hubungan darah sebagai ayahnya dan tidak mempunyai kekuatan mengikat sepanjang dimaknai seperti itu."

Pasal 43 Ayat (1) UU Perkawinan menurut Mahkamah Konstitusi harus dibaca sebagai berikut:

"Anak yang dilahirkan di luar perkawinan mempunyai hubungan perdata dengan ibunya dan keluarga ibunya serta dengan laki-laki sebagai ayahnya yang dapat dibuktikan berdasarkan ilmu pengetahuan dan teknologi dan/atau alat bukti lain menurut hukum mempunyai hubungan darah, termasuk hubungan perdata dengan keluarga ayahnya."

\section{E. Penutup}

Konstitusionalisasi hukum privat menjadi kajian yang cukup menarik mengingat adanya pembagian bidang ilmu hukum dan konstitusionalisasi ini menjadi salah satu bentuk persinggungan di antara keduanya. Pengaruh perkembangan pemikian tentang jaminan HAM dalam konstitusi (fundamental rights) dan kehadiran peradilan konstitusi turut memperkaya pengkajian terhadap konstitusionalisasi hukum privat ini. Pada satu sisi, jaminan hak asasi dalam konstitusi bernilai positif karena dengan adanya jaminan dari norma hukum tertinggi atas hak-hak tersebut tentunya lebih menjamin kepastian hukum. Namun, pada sisi yang lain terdapat kekhawatiran dengan konstitusionalisasi hukum privat. Hal tersebut dikhawatirkan semakin memperkuat dominasi negara terhadap kehidupan rakyatnya, walaupun sebenarnya jika ditinjau dari masing-masing antara hukum privat dan konstitusi, keduanya adalah untuk melindungi hak, terutama hak individu.

\section{Daftar Pustaka}

\section{Buku}

Achmad Sanusi, Pengantar Ilmu Hukum dan Pengantar Tata Hukum Indonesia, Edisi Ke IV, Penerbit Tarsito, Bandung, 2002.

Alder, John, General Principles of Constitutional Law and Administrative Law, Fourth Edition, Palgrave Macmillan, Hampshire, 2002.

Bagir Manan, Pertumbuhan dan Perkembangan Konstitusi Suatu Negara, Penerbit CV. Mandar Maju, Bandung, 1995.

Barent, Eric, An Introduction to Constitutional Law, Oxford University Press, Oxford, 1998. 
Rahayu Prasetianingsih: Konstitusionalisasi Hukum Privat: Beberapa Pandangan yang Berkembang dalam Pengkajian Ilmu Hukum

Barkhuysen, Tom and Siewert D. Lindenbergh (eds), Constitutionalisation of Private Law, Martinus Nijhoff Publishers, Leiden, 2006.

Engelbrekt, Antonina Bakardjieva (eds), New Direction of Comparative Law, Edward Elgar Publishing Limited, Cheltenham, 2010.

Freedland, Mark and Jean-Bernard Auby (eds), The Public Law/Private Law Divide, Volume 2 in The Series: Studies of The Oxford Institute of European and Comparative Law, Hart Publishing, Portland, 2006.

Friedmann, Daniel and Daphne Barak-Erez (eds), Human Rights in Private Law, Hart Publishing, Portland, 2001.

Markesinis, Basil, German Law of Obligations, Volume 2 The Law of Torts: A Comparative Introduction, Hart Publishing, Portland, 1998.

Menendez, A.J., E. O. Eriksen (eds), Arguing Fundamental Rights, Springer, Dordrecht, 2006.

Rickett, Charles and Ross Grantham (eds), Structure and Justification in Private Law Essay for Peter Birks, Hart Publishing, Portland, 2008.

Sri Soemantri, Pengantar Perbandingan Antar Hukum Tata Negara, Penerbit CV. Rajawali, Jakarta, 1984.

Strong, C.F., Modern Political Constitution, Sidgwick \& Jackson, London, 1952.

Twigg-Flesner, Christian (ed.), The Cambridge Companion to European Union Private Law, 2011, Cambridge University Press, Cambridge, 2010.

Utrecht, E., M. Saleh Djindang, Pengantar Dalam Hukum Indonesia, Cet. Kesebelas, Penerbit \& Balai Buku Ichtiar, Jakarta, 1989.

Van Caenegern, R. C., An Historical Introduction to Private Law, terjemahan D. E. L. Johnston, Reprinted, Cambridge University Press, Cambridge, 1996.

Zoller, Elizabeth, Introduction to Public Law: A Comparative Study, Martinus Nijhoff Publishers, Leiden, 2008.

\section{Dokumen Lain}

Fabbrini, Sergio, "Constitutionalization as an Open Process: Constituting Compound Polities From Philadelphi a to Brussels", <http://web.unitn.it/files/download/9722/wpfabbrini.pdf>

Linden, Allen M., "Public Law and Private Law: Their Frontier from the Perspective of a Tort Lawyer", Les Cahier de Droit, Vol. 17, Issue 4, 1976, <http://id.erudit.org/iderudit/042139ar>

Nolan, Donal, Andrew Robertson. "Rights and Private Law", <http://www.hartpub.co.uk/pdf/samples/9781849461429sample.pdf> 
Rahayu Prasetianingsih: Konstitusionalisasi Hukum Privat: Beberapa Pandangan yang Berkembang dalam Pengkajian Ilmu Hukum

\section{Dokumen Hukum}

UUD Negara Republik Indonesia Tahun 1945

Undang-Undang No. 14 Tahun 1974 tentang Perkawinan

Putusan Mahkamah Konstitusi No. 46/PUU-VIII/2010 tentang Pengujian UU No. 1

Tahun 1974 tentang Perkawinan 